Olena lastremska,

Dc.Sc., Professor, Simon Kuznets Kharkiv National University of Economics, Ukraine

ID ORCID ID, 0000-0002-5653-6301

e-mail: lastremska_om@hneu.net

Hanna Strokovych,

Dc.Sc., Associated Professor, Simon Kuznets Kharkiv National University of Economics, Ukraine

DORCID ID, 0000-0002-5092-9059

e-mail: annastrokovych@gmail.com

Olesia lastremska,

Ph.D., Associated Professor, Simon Kuznets Kharkiv National University of Economics, Ukraine;

DORCID ID, 0000-0003-1865-0282

e-mail: lastremska.o@gmail.com;

Christos Kalantaridis,

Ph.D., Professor, London Metropolitan University, Great Britain

IDORCID ID, 0000-0002-3781-9461

e-mail: C.kalantaridis@londonmet.ac.uk

Szabolcs Nagy,

Ph.D., University of Miskolc, Hungary

ID ORCID ID, 0000-0002-1886-0848

e-mail: nagy.szabolcs@uni-miskolc.hu

Mariann Veresne Somosi,

PhD., University of Miskolc, Hungary

ID ORCID ID, 0000-0001-8220-8232

e-mail:szvvsm@uni-miskolc.hu

Correspondence author: iastremska_om@hneu.net

\title{
FORMATION OF MUTUAL RELATIONS BETWEEN ENTERPRISES AND BUSINESS PARTNERS IN THE PROCESS OF PREPARATION AND PRODUCTION OF NEW PRODUCTS
}

\begin{abstract}
This article summarizes the scientific approaches to improving the quality of relations between the enterprise and business partners in preparation for the release and production of new products in today's economic realities. The study's main purpose is to substantiate and develop a methodological approach for determining effective relationship models between enterprises and business partners to prepare and produce new products. The article presents a developed four-stage methodological approach. The first stage of the study presents an analysis of existing approaches to forming relationships between the enterprise and business-business partners to prepare and produce new products. In the second stage, factual data on machine-building industry enterprises' functioning were collected to determine the effectiveness of cooperation and success, which are the key components that improve the quality of relations between the enterprise and business partners in preparing new products. At the third stage, partners' priority was determined to characterize the quality of the relationship between machine-building enterprises and businessbusiness partners. The fourth stage determined the relationship between the qualitative levels of business partners' priority and appropriate relationship models to prepare and produce new products. The study used expert methods, multidimensional factor analysis, additive convolution method, structural-logical method, graphical method. A survey of enterprise representatives was conducted to assess the effectiveness of cooperation on 12 surveyed machinebuilding enterprises. Partial indicators were identified and substantiated by multidimensional factor analysis,
\end{abstract}

Cite as: lastremska, O., Strokovych, H., lastremska, O., Kalantaridis, C., Nagy, S., \& Somosi Veresne, M. (2021). Formation of Mutual Relations Between Enterprises and Business Partners in the Process of Preparation and Production of New Products. Marketing and Management of Innovations, 1, 196-211. http://doi.org/10.21272/mmi.2021.1-15

196

Received: 13 January 2021 
O., lastremska, U., Strokovych, O., lastremska, C., Kalantaridis, S., Nagy, M., Somosi Verense. Formation of Mutual Relations Between Enterprises and Business Partners in the Process of Preparation and Production of New Products

generalized for making decisions about business partner enterprises' existing opportunities to prepare and produce new products. Based on the calculation of the integrated indicator, partners' priority was determined. That characterized the quality of relations between machine-building enterprises and business-business partners in preparing and producing new products. According to the Harrington scale specified for the economic conditions of Ukraine, the qualitative levels of partner companies' priority were determined. The proposed effective models of relationships for preparing and producing new products are put in line with them. The study results could improve the quality and validity of the formation and maintenance of relationships between enterprises and business partners in preparing and producing new products.

Keywords: new products, effectiveness, cooperation, success, functioning, business partner, relationship.

Introduction. The dynamic development of technology leads to the need to constantly improve existing products, develop and implement fundamentally new ones that will allow companies to create certain competitive advantages that will contribute to the constant growth of their competitiveness. At the same time, in the production of new products, companies are particularly active in cooperating with business partners, which directly affects their ability to manufacture high-quality, competitive, innovative products. That necessitates a critical analysis of approaches to forming the relationship between the enterprise and business partners in producing new products. Besides, that is especially true for machinebuilding enterprises. Therefore, it is important to identify existing approaches to the relationship between the company and business partners in preparation for the release of new products and their production. That is determined by the effectiveness of enterprises' cooperation and success and characterizes business partners' priority for the company. Thus, the proposed study aims to improve and further develop existing approaches in the scientific discourse on forming relationships between enterprises and business partners in preparation for the release and production of new products.

Literature Review. Collaboration is an inter-organizational relationship focused on technological innovation's joint development (Powell et al., 1996; Ahuja, 2000; Stewart, 2000). Such relationships use a common approach to innovation, which involves a combination of knowledge, technology, and other resources. Collaboration allows partners to take advantage of both an open innovation approach that uses new external resources (Chesbrough, 2003; O'Mahony and Ferraro, 2007) and a closed innovation approach that protects the ownership of contract-based innovation (Gans et al., 2002; Mayer and Argyres, 2004). Preliminary research gives some idea of the cooperation effectiveness in the field of technology. The emphasis is primarily on structural innovation. Research has shown that technology collaboration between organizations with powerful research and development capabilities and relevant complementary technologies could be highly effective (Hagedoorn, 1993; Ahuja, 2000; Stuart, 2000). Cooperation with effective management and business partners with extensive cooperation experience, based on the relationship of trust, could also be highly effective (Gulati, 1995; Uzzi, 1996; Anand and Khanna, 2000; Kale et al., 2002). Many collaborating organizations use intellectual property protection forms such as trade secrets (Katila et al., 2008) and achieve other results, such as new products (Katila, 2002). Alliance research showed that performance indicators (such as duration) were mainly used to address using different relationships (Doz, 1996). However, the relationship duration is a problematic indicator, as business partners often break off technological cooperation when their innovation goals were realized, i.e., enterprises succeed (Arino and De La Torre, 1998). A major challenge in managing technology collaboration is that partners have their own well-established innovation processes that could conflict (Davis and Eisenhardt, 2011). Also, partners will have different decision-making rules for research management, pursue clear product-market goals, and have people with very different levels of competencies (Allen, 1977; Clark, 1991; Brown and Eisenhardt, 1997). Reconciling these differences requires recombining business partners' aspects without overly restricting innovation to too large a structure (Davis et al., 2009). Relevant preconditions could be general. This coordination of the decisionmaking process, goals, and participants takes place mainly during joint work (Davis and Eisenhardt, 2011). 
O., lastremska, U., Strokovych, O., lastremska, C., Kalantaridis, S., Nagy, M., Somosi Verense. Formation of Mutual Relations Between Enterprises and Business Partners in the Process of Preparation and Production of New Products

It suggests that the understanding of the process of forming a relationship between the company and business partners in preparation for the release and production of new products may be much smaller than it initially seemed.

Methodology and research methods. This study involved the scientific approaches to improve the quality of relations between enterprises and business partners in preparation for the release and production of new products to justify decisions on business partners' choices based on their priority. That was proposed to define in two aspects: effectiveness of cooperation and successful operation. The study is based on the generalization of existing scientific and theoretical approaches and studying the machinebuilding industry's actual data. For ensuring an integrated approach to the research, a four-stage methodological approach is proposed and used. The first stage of the study provided an analysis of existing approaches to forming the relationship between the enterprise and business partners in preparing for the release of new products. The second stage collected factual data on machine-building enterprises' functioning to determine the effectiveness of cooperation and success, i.e., the key factors that improve the quality of relations between the enterprise and business partners preparing for production and producing new products. At the third stage, the partners' priority was determined. It characterizes the quality of relations between machine-building enterprises and business partners in preparation for the release and production of new products. In the fourth stage, the relationship between partners' quality levels and appropriate models of relationships to produce new products were determined. For research, the authors selected 12 enterprises of the machine-building industry. These enterprises are representatives of their various subsectors. For each of them, an analysis was conducted on such aspects as the effectiveness of cooperation and the operation's success, which characterize the priority of cooperation with business partners. For providing the quality of relations between the enterprise and business partners in the process of preparing for production and producing new products to affect the results of cooperation positively, ensure their stability, efficiency, and integration, it is advisable to pay attention to the effectiveness of cooperation, namely efficiency, and consequence. They should deepen the manufacturer's key competencies, ensuring its strategic position in the market. This study involved expert methods. Thus, the questionnaire was developed and offered to experts (managers of enterprises) to assess the effectiveness of cooperation for 12 surveyed machine-building enterprises using a 5-point scale. Experts representing manufacturers by each characteristic corresponding to a certain component of the cooperation effectiveness rated the relevant partners with whom they come into contact in points from 0 to 5 . Herewith, 5 corresponds to the assessment «excellent»; 0 - «unsatisfactory» or this characteristic is not inherent in the enterprise.

Using the assessments provided by experts on the characteristics of the cooperation effectiveness (CE) by the additive convolution method, an integrated indicator is calculated that takes into account the views of experts (managers) on the benefits of the relationship between enterprise and business partners in preparation for production and production of new products:

$$
C E=\sum_{i=1}^{n} k_{\text {signi }} \frac{x_{\text {acti }}}{x_{\text {refi }}}
$$

where $n$ - the number of proposed characteristics of the components of the cooperation results for the qualitative component of the partners' evaluation; $k_{\text {signi }}$ - coefficient of the significance of the i-th characteristics of the cooperation effectiveness for the qualitative component of the partners' evaluation; $\mathrm{X}_{\text {acti }}$ - the actual value of the $\mathrm{i}$-th characteristics of the components of the cooperation effectiveness in the qualitative component of the partners' evaluation; $\mathrm{X}_{\text {refi }}$ - the reference value of the i-th characteristics of the components of the cooperation effectiveness in the qualitative component of the partners' evaluation, which is equal to 5 points. 
O., lastremska, U., Strokovych, O., lastremska, C., Kalantaridis, S., Nagy, M., Somosi Verense. Formation of Mutual Relations Between Enterprises and Business Partners in the Process of Preparation and Production of New Products

The success of the relationship between the enterprise and business partners in preparation for the release and production of new products is ensured by the efficient use of economic resources and positive trends in innovation. Thus, only capable of developing enterprises could be priority business partners that form competencies to meet new products' demand. Data from 12 machine-building enterprises of the Kharkiv region were used to determine the general economic trends of machine-building enterprises (as partners that characterize the microeconomic level) and their internal environment (depends on the external environment). For identifying trends inherent in these enterprises in the success of functioning, it is advisable to use the data of official statistical reporting to calculate the indicators that characterize their activities. It is advisable to use multidimensional factor analysis to increase the reliability and update the resulting data,. Besides, it was carried out in two stages: 1) separately by resource and innovation. Thus, the first stage provided separation of the most important indicators to finalize the performance indicators system of machine-building enterprises in preparation for production and production of new products. The second stage was to combine the most significant indicators identified in each area and implement them into multidimensional factor analysis to finally clarify the composition of the indicators system of the enterprises functioning success. Partial indicators, defined and substantiated by multidimensional factor analysis, should be summarized for final decisions about partner companies' existing opportunities to prepare for and produce new products. That is is an important factor in determining the types of relationships and patterns of application. Many methods could carry out generalization. However, since all indicators characterize a holistic phenomenon (the success of functioning) and their significance could weigh them, such generalization should be carried out by additive coagulation, considering the standardization of significance factors (factor loads), multidimensional factor analysis, normalization of quantitative values of partial indicators. According to the formula of the integrated indicator using the method of additive convolution (to achieve methodological unity of the calculation of integrated indicators), the success of functioning was calculated by the actual quantitative values of indicators based on official statistics for the surveyed enterprises:

$$
S F=\sum_{j=1}^{m} l_{\text {signi }} \frac{y_{\text {acti }}}{y_{\text {refi }}},
$$

where $\mathrm{m}$ - the number of partial indicators of the enterprise functioning success; Isigni $_{\text {- the significance }}$ coefficient of the j-th partial indicator of the enterprise functioning success; yacti - the actual value of the jth partial indicator of the enterprise functioning success; yrefi - reference value of the j-th partial indicator of the enterprise functioning success.

The integrated indicator's quantitative values were calculated to identify priority partners that could meet and ensure the necessary efficiency, consequent cooperation, and meet the producers' demand based on the efficient use of economic resources. The formula calculates the integrated indicator of the business partner priority in choosing the relationship with him manufacturers in the process of preparation for the release and production of new products:

$$
B P P=V_{S F} S F+V_{C E} X C E,
$$

where VSF - the significance coefficient of the integrated indicator of the partner functioning success; SF - the integrated indicator of the partner functioning success; VCE - the significance coefficient of the integrated indicator of the cooperation effectiveness with the business partner in the process of preparation for the release and production of new products (according to the manufacturer); CE - an integrated indicator of the cooperation effectiveness in the process of preparation for the release and production of new products (according to the manufacturer).

The analysis of the relationship between the enterprise and business partners in the process of preparation for the release and production of new products used: multidimensional factor analysis - to 
O., lastremska, U., Strokovych, O., lastremska, C., Kalantaridis, S., Nagy, M., Somosi Verense. Formation of Mutual Relations Between Enterprises and Business Partners in the Process of Preparation and Production of New Products

justify the system of the enterprise success indicators; additive convolution method - to determine the integrated indicators; structural-logical method - to substantiate the methodological approach and determine the relationship between the priority of the business partner and the model of the relationship with him of the manufacturer; method of expert evaluations - to determine the characteristics of the cooperation effectiveness in the process of preparation for the release and production of new products; graphic - to visualize the results.

Results. For determining the characteristics in the process of preparation for the release and production of new products on the proposed components of the cooperation effectiveness, which determine both the choice of partner and the type of relationship between the manufacturer and him, a questionnaire was developed. According to the questionnaire, experts were asked to name the characteristics of the efficiency components and consequences of cooperation. Thus, these data allowed characterizing it from the manufacturer's standpoint, which is impossible to determine based on official statistics. Besides, the respondents characterized interaction with business partners in qualitative terms, both objective and subjective ideas about the release of new products. According to the questionnaire, 12 experts were interviewed. They are the leading specialists and heads of innovation, logistics, and marketing departments of machine-building enterprises. The experts' selection was carried out following the activities analysis results to produce new products by the studied enterprises, which are closely related. The experts' quality was checked based on self-assessment of their professionalism, which was relatively high. Thus, it confirmed the quality of the experts' group. According to the questionnaire, the experts were asked to name the characteristics of the components of the effectiveness of cooperation in preparing a business partner for the production and producing new products, in qualitative terms, considering both practical objective knowledge and subjective perceptions of profitability. Table 1 presents the obtained survey results.

Table 1. Qualitative characteristics of the cooperation effectiveness of industrial enterprises with business partners

\begin{tabular}{|c|c|c|}
\hline Component & Characteristics & $\begin{array}{c}\% \text { experts responses who noted the } \\
\text { significance and importance of the } \\
\text { characteristics, } \%\end{array}$ \\
\hline \multirow{8}{*}{$\begin{array}{l}\text { Effectiveness } \\
\text { of } \\
\text { cooperation }\end{array}$} & $\begin{array}{l}\text { 1. Profitability of conditions of production and } \\
\text { service delivery. }\end{array}$ & 88,97 \\
\hline & 2. The advantage of the payment terms by term & \\
\hline & $\begin{array}{l}\text { 2. Ine advantage of the payment terms by term } \\
\text { and form. }\end{array}$ & 86,94 \\
\hline & 3. Reducing the cost of concluding a contract. & 96,87 \\
\hline & 4. Flexibility of contract change conditions. & 93,34 \\
\hline & $\begin{array}{l}\text { 5. Reliability of the relationship in the process of } \\
\text { creating new products. }\end{array}$ & 83,32 \\
\hline & 6. Satisfaction with the terms of cooperation. & 80,0 \\
\hline & 7. Achievability of innovative goals. & 85,63 \\
\hline \multirow{4}{*}{$\begin{array}{l}\text { Consequenc } \\
\text { e of } \\
\text { cooperation }\end{array}$} & $\begin{array}{l}\text { 8. Improving customer service of the enterprise } \\
\text { when buying new products. }\end{array}$ & 82,73 \\
\hline & $\begin{array}{l}\text { 9. Improving the quality of innovative products. } \\
\text { 10. Growth of image as innovators of the }\end{array}$ & 93,33 \\
\hline & $\begin{array}{l}\text { enterprise-manufacturer and the enterprise- } \\
\text { partner. }\end{array}$ & 89,02 \\
\hline & $\begin{array}{l}\text { 11. The growth of the manufacturer's brand value } \\
\text { and the partner company in terms of innovation. }\end{array}$ & 93,31 \\
\hline
\end{tabular}

Sources: developed by the authors. 
O., lastremska, U., Strokovych, O., lastremska, C., Kalantaridis, S., Nagy, M., Somosi Verense. Formation of Mutual Relations Between Enterprises and Business Partners in the Process of Preparation and Production of New Products

According to Table 1, the cooperation effectiveness in terms of new products is ensured by influencing the four characteristics. The first is the low level of costs for implementing the relationship, due to the cost of the entire cycle of activities for the production of new products, namely - the cost of negotiations, conclusion, and signing of supply contracts, innovation management, and production costs. The second is the flexibility of the terms of the contract for the supply. That provides the possibility of changing the terms of delivery by the number of payments, the form of payment, amount of funds, and certain risks. The third is the profitability of the terms of delivery of products from the partner, which means the terms of delivery time, batch size, location, number of deliveries, method of delivery, conditions, storage costs; conditions of after-sales maintenance, as the partner's products have production and technical purpose. The fourth is the profitability of payment terms for the supply of products affected by the term and payment form. That is the possibility of obtaining a deferral in the form of trade credit or subscription, receiving discounts on the number of goods, delivery time, number of deliveries.

The experts identified the component of the cooperation consequences according to seven characteristics, which are:

- improving product quality through the use of new materials, design solutions, functional expansion, and adaptation of products to new consumer needs; the implementation of additional values relevant to consumers;

- growth of the enterprise-manufacturer and the enterprise-partner brands' value on an innovative component that strengthens their strategic positions, allows to implement corporate and functional strategies, promotes the efficiency of use of strategic, competitive, production, and market potential of the enterprise:

- creating additional positive impressions of the image of the manufacturer, improving its image by informing suppliers as reliable partners, having domestic and international awards as the best manufacturers, well-known brands, well-established financial position, the market value of which is constantly growing;

- achieving the goals of cooperation, which allow to reduce the risks of production and procurement, diversify production or take the lead based on the concentration of production or development of innovative, new to the market, i.e., mutational products;

- satisfaction with the relationship, providing a partner with a high level of satisfying the manufacturer's needs. In turn, the satisfaction is to achieve a certain level of compliance with the expectations of the manufacturer, a positive result of cooperation compared to alternative supply options, achieving consumer satisfaction with the final products of the manufacturer, the prospects for the development of relationships, their personalization;

- improving customer service through the creation of service networks, the use of joint supply networks, which creates a synergy of procurement;

- interdependence of the manufacturer from the partner could be formed in the course of activity concerning the release of new products. Herewith, the interdependence means the reliability and profitability of the relationship, determined by such factors as technology (which consist in the use of joint production technologies, logistics technologies, the transfer of certain technological operations or functions to the supplier); organizational (which consist in participation in joint associations, unions, corporations, projects, signing of strategic partnership agreements); social (connecting buyers and sellers through personal contacts, the absence of conflict situations in the procurement process). Thus, interdependence is seen as a stimulant characteristic that contributes to the relationship's stability and profitability.

The list of characteristics for the cooperation effectiveness components was determined based on the expert ranking method provided the evaluation of significance. The consistency of the experts' opinions confirms the calculation of the concordance coefficient, which is 0.74 . Therefore, it allows asserting the 
O., lastremska, U., Strokovych, O., lastremska, C., Kalantaridis, S., Nagy, M., Somosi Verense. Formation of Mutual Relations Between Enterprises and Business Partners in the Process of Preparation and Production of New Products

non-randomness of the experts' answers, their significant consistency, and expediency of use in further research. The values of the significant coefficients of the characteristics and components of the enterprise's effectiveness of cooperation with the enterprises and business partners were calculated as the weighted average according to experts' answers (Table 2).

Table 2. Significance coefficients of characteristics and components of cooperation efficiency at the formation of mutual relations of the enterprises-manufacturers with business partners

\begin{tabular}{clc}
\hline Component & \multicolumn{1}{c}{ Characteristics } & \multicolumn{1}{c}{$\begin{array}{c}\text { Significance } \\
\text { coefficient of the } \\
\text { characteristic }\end{array}$} \\
\hline Effectiveness of & $\begin{array}{l}\text { 1. Profitability of terms of delivery of products for service. } \\
\text { 2. Profitability of the terms of payment by term and form of } \\
\text { payment. }\end{array}$ & 0,0914 \\
& $\begin{array}{l}\text { 3. Reducing the cost of concluding a contract. } \\
\text { 4. Flexibility of contract change conditions }\end{array}$ & 0,0893 \\
& $\begin{array}{l}\text { 5. Reliability of the relationship in the process of creating new } \\
\text { products. }\end{array}$ & 0,0995 \\
& $\begin{array}{l}\text { 6. Satisfaction with the terms of cooperation. } \\
\text { 7. Achievability of the set of innovative purposes. }\end{array}$ & 0,0959 \\
consequence of & $\begin{array}{l}\text { 8. Improving customer service of the enterprise when buying new } \\
\text { products. }\end{array}$ & 0,0856 \\
& $\begin{array}{l}\text { 9. Improving the quality of innovative products. } \\
\text { 10. Growth of image as innovators of the enterprise-manufacturer }\end{array}$ & 0,0880 \\
& $\begin{array}{l}\text { and the enterprise-partner. } \\
\text { 11. The growth of the brands' value of the manufacturer and the } \\
\text { partner company in terms of innovation }\end{array}$ & 0,0850 \\
\hline
\end{tabular}

Sources: developed by the authors.

According to the results of the evaluation (Table 2), the greatest influence on the component of the effectiveness of cooperation with business partners in terms of significance had the characteristic «Reduction of contract costs» (0.0995). That embodied the benefits of supply terms from the partner by delivery time, batch size, place, number of deliveries, delivery method, conditions, storage costs, conditions of after-sales maintenance, as the partner's products had production and technical purpose. According to the developed proposals, integrated evaluation indicators of the enterprise's cooperation effectiveness with business partners for the studied 12 machine-building enterprises were calculated. Table 3 shows the obtained values of the integrated indicators.

Table 3. Quantitative values of integrated indicators of the component of the manufacturers' cooperation effectiveness with business partners

\begin{tabular}{lc}
\hline \multicolumn{1}{c}{ Name of Company } & $\begin{array}{c}\text { The value of the integrated } \\
\text { indicator }\end{array}$ \\
\hline PJSC «Kharkiv Bearing Plant» & 0,98092 \\
JSC «Turboatom» & 0,96422 \\
PJSC Pivdenkabel Plant & 0,81708 \\
PJSC «Vovchansky Aggregate Plant» & 0,81998 \\
State Enterprise «Kharkiv Machine-Building Plant» FED» & 0,83754 \\
SE «Electrovazhmash Plant» & 0,76306 \\
PJSC «Electromachine» & 0,761 \\
PJSC Kharkiv Electrotechnical Plant Ukrelectromash & 0,7809 \\
PJSC «Plant. Frunze» & 0,78308 \\
PJSC «Kharkiv Tractor Plant» & 0,61924 \\
\hline
\end{tabular}


O., lastremska, U., Strokovych, O., lastremska, C., Kalantaridis, S., Nagy, M., Somosi Verense. Formation of Mutual Relations Between Enterprises and Business Partners in the Process of Preparation and Production of New Products

Continued Table 3

\begin{tabular}{lc}
\hline PJSC «Kharkiv Machine-Building Plant» Korum Svitlo Shakhtyar» & 0,61924 \\
\hline Private JSC «Kharkiv Plant of Stamps and Molds» & 0,65486 \\
\hline Sources: developed by the authors. &
\end{tabular}

According to Table 3, the greatest quantitative value of the component of the cooperation effectiveness between enterprises and business partners, considering the subjective nature of the relationship, has estimates of the following partner companies: PJSC «Kharkiv Bearing Plant» (0.98092), OJSC Turboatom (0.96422), PJSC Pivdenkabel Plant (0.81708), PJSC Vovchansky Aggregate Plant (0.81998), the least PJSC Kharkiv Machine-Building Plant Corum Svitlo Shakhtar (0.61924), Private JSC «Kharkiv Plant of Stamps and Molds» (0.65486). The developed methodological proposals were based on expert methods, appropriated for qualitative assessment of components that consider certain phenomena' subjective nature and are probabilistic. The methods of accurate quantitative calculations require the official use of statistical reporting. According to the proposed methodological approach, the study's next stage was to determine the enterprise's success. The method of factor analysis by the method of rotation Varimax raw allowed to obtain significant values of factors for the accumulated variance: for the resource direction, Figure 2 presents its value, Figure 3 - innovation. The analysis results showed that the four obtained factors described $78,68 \%$ variance of the entire primary list of factors for the resource direction (Figure 2) and $77.01 \%$ - for the analysis's innovative direction (Figure 4).

\begin{tabular}{|c|c|c|c|c|}
\hline \multirow[b]{2}{*}{ Variable } & \multicolumn{4}{|c|}{$\begin{array}{l}\text { Factor Loadings (Varimax raw) (Spreadsheet32) } \\
\text { Extraction: Principal components } \\
\text { (Marked loadings are }>700000 \text { ) }\end{array}$} \\
\hline & $\begin{array}{c}\text { Factor } \\
1\end{array}$ & \begin{tabular}{|l|} 
Factor \\
2
\end{tabular} & $\begin{array}{c}\text { Factor } \\
3\end{array}$ & $\begin{array}{c}\text { Factor } \\
4\end{array}$ \\
\hline Var1 & 0,494233 & 0,302431 & 0,622337 & $-0,00309$ \\
\hline Var2 & 0,537221 & $-0,042249$ & 0,694419 & $-0,125106$ \\
\hline Var3 & $-0,0$ & 4 & 53 & 48072 \\
\hline Var4 & & & & \\
\hline Var5 & 42 & 20 & 04 & 763681 \\
\hline Var6 & & & & \\
\hline Var7 & $-0,042$ & 930 & .045 & 8731 \\
\hline Var8 & & 7 & 0.45 & $-0,099018$ \\
\hline Var9 & & -0.06 & $-0,02$ & 0.056494 \\
\hline Var10 & 0,953392 & $-0,071205$ & 0,024759 & $-0,087108$ \\
\hline NewVar1 & 0708082 & -0.097 & 0.010921 & 0,301406 \\
\hline NewV: & 0.713 & $-0,036232$ & $-0,091407$ & 0,058405 \\
\hline NewVar3 & $-0,0353$ & 0.977 & 0,032794 & 0.087919 \\
\hline NewV & & & & 0,247257 \\
\hline NewVar5 & 0,953392 & -0.071205 & 0,024759 & $-0,087108$ \\
\hline NewVar6 & $-0,079936$ & 0,056954 & 0,951253 & 0.048072 \\
\hline Expl.Var & 4,692478 & 3,656610 & 3,004621 & 1235 \\
\hline Prp.Totl & 0.293280 & 0.228538 & 0.187789 & 0.077206 \\
\hline
\end{tabular}

Figure1. Factor load of indicators on the resource direction of the analysis Sources: developed by the authors.

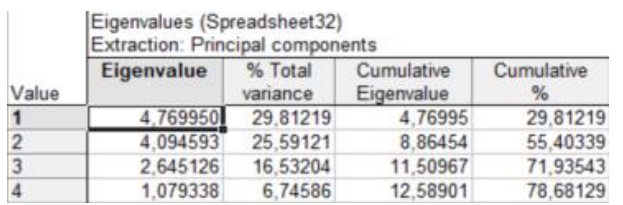

Figure 2. The accumulated variance of factors by resource direction of analysis Sources: developed by the authors.

Since $70 \%$ of the accumulated variance is sufficient for the reliability of the analysis results, the number of factors in both analysis directions is sufficient. Thus, it explains $78,68 \%$ of data variation by resource direction and $77.01 \%$ - by innovation. 
O., lastremska, U., Strokovych, O., lastremska, C., Kalantaridis, S., Nagy, M., Somosi Verense. Formation of Mutual Relations Between Enterprises and Business Partners in the Process of Preparation and Production of New Products

\begin{tabular}{|c|c|c|c|c|}
\hline \multirow[b]{2}{*}{ Variable } & \multicolumn{4}{|c|}{$\begin{array}{l}\text { Factor Loadings (Varimax raw) (Spreadsheet5) } \\
\text { Extraction: Principal components } \\
\text { (Marked loadings are }>, 700000)\end{array}$} \\
\hline & $\begin{array}{c}\text { Factor } \\
1\end{array}$ & $\begin{array}{c}\text { Factor } \\
2\end{array}$ & $\begin{array}{c}\text { Factor } \\
3\end{array}$ & $\begin{array}{c}\text { Factor } \\
4\end{array}$ \\
\hline Var1 & 0.446068 & $-0,095438$ & 0,732067 & $-0,144104$ \\
\hline Var2 & $-0,052394$ & 0,122858 & 0.888727 & 0,114823 \\
\hline Var3 & $-0,047907$ & 0,924930 & 0,068399 & 0,001909 \\
\hline $\operatorname{Var} 4$ & $-0,167192$ & 0,608789 & $-0,123609$ & $-0,036351$ \\
\hline Var5 & 0,589279 & 0,513771 & $-0,139842$ & 0,094362 \\
\hline Var6 & $-0,000128$ & 0.928015 & 0.039331 & 0.107607 \\
\hline Var7 & $-0,302379$ & 0,623702 & 0,528878 & 0.111609 \\
\hline Var8 & 0.897013 & $-0,075014$ & 0,016419 & -0.205202 \\
\hline Var9 & 0.899142 & $-0,134452$ & 0,122111 & $-0,203684$ \\
\hline Var10 & 0,777474 & $-0,008538$ & $-0,016670$ & $-0,084839$ \\
\hline NewVar1 & 0,505743 & $-0,009769$ & $-0,013498$ & $-0,778119$ \\
\hline NewVar2 & -0.073680 & 0.094580 & 0.043304 & 0.930252 \\
\hline Expl.Var & 3,149411 & 2.797315 & 1,664047 & 1.629846 \\
\hline Prp.Totl & 0,262451 & 0.233110 & 0,138671 & 0,135820 \\
\hline
\end{tabular}

Figure 3. Factor load of indicators on the innovative direction of the analysis

Sources: developed by the authors.

\begin{tabular}{|c|c|c|c|c|}
\hline \multirow[b]{2}{*}{ Value } & \multicolumn{4}{|c|}{$\begin{array}{l}\text { Eigenvalues (Spreadsheet5) } \\
\text { Extraction: Principal components }\end{array}$} \\
\hline & Eigenvalue & $\begin{array}{l}\% \text { Total } \\
\text { variance }\end{array}$ & $\begin{array}{l}\text { Cumulative } \\
\text { Eigenvalue }\end{array}$ & $\begin{array}{c}\text { Cumulative } \\
\%\end{array}$ \\
\hline 1 & 3,777104 & 31,47587 & 3,777104 & 31,47587 \\
\hline 2 & & 22,92730 & 6,528380 & 54,40317 \\
\hline 3 & 1,575022 & 13,12518 & 8.103402 & 67,52835 \\
\hline & & (5) & $e^{2}$ & \\
\hline
\end{tabular}

Figure 4. The accumulated variance of factors in the innovative direction of analysis Sources: developed by the authors.

Thus, the indicators selected by factor loads at the first stage of factor analysis should be selected and combined into a system that would reliably explain the existing trends in machine-building enterprises' success and could be used for further refinement and selective selection of its composition. Table 4 shows the system of indicators.

Table 4. System of indicators of functioning success of the machine-building enterprises on resource and innovative directions

\begin{tabular}{lc}
\hline \multicolumn{1}{c}{ Indicator name Indicator code } & $\begin{array}{c}\text { Indicator } \\
\text { code }\end{array}$ \\
\hline Resource direction & \\
Financial resources & $\mathrm{R} 1$ \\
Coefficient of financial autonomy & $\mathrm{R} 2$ \\
Profitability of sales & $\mathrm{R} 3$ \\
Solvency ratio & $\mathrm{R} 4$ \\
Liquidity ratio & $\mathrm{R} 5$ \\
Coefficient of financial stability & \\
Material resources & $\mathrm{R} 6$ \\
Fixed assets renewal rate & $\mathrm{R} 7$ \\
Return on assets & $\mathrm{R} 8$ \\
Capital adequacy & $\mathrm{R} 9$ \\
Material efficiency & \\
Information resources & $\mathrm{R} 10$ \\
\hline
\end{tabular}


O., lastremska, U., Strokovych, O., lastremska, C., Kalantaridis, S., Nagy, M., Somosi Verense. Formation of Mutual Relations Between Enterprises and Business Partners in the Process of Preparation and Production of New Products

\begin{tabular}{lc} 
& Countinued Table 4 \\
\hline The share of costs for participation in exhibitions and other image events in the total cost of & $\mathrm{R} 11$ \\
sales & $\mathrm{R} 12$ \\
The share of investment in software in the total investment in informatization & \\
Innovative direction & $\mathrm{I}$ \\
Indicators of innovation activity & 12 \\
The share of employees performing scientific and technical work & 13 \\
The share of current costs of technological innovation in the total cost of innovation & 14 \\
The share of long-term investment in technological innovation in the total cost of innovation & 15 \\
The share of spending on research and development in the total cost of innovation & 16 \\
The share of costs for technological preparation of production in the total cost of innovation & \\
The share of expenditures on machinery, equipment, tools, other fixed assets, and capital & 17 \\
expenditures related to the implementation of innovations in the total expenditures on & 18 \\
innovations & 19 \\
The share of marketing and advertising costs in the total cost of innovation & \\
The share of innovative products in the total volume shipped & \\
The share of shipped products produced with significant technological changes or re- & \\
introduced within three years in the total volume of shipped products &
\end{tabular}

The application of multidimensional factor analysis using a selected system of indicators in both directions by rotation Varimax raw type allowed selecting factors whose characteristics are shown in Figure 5.

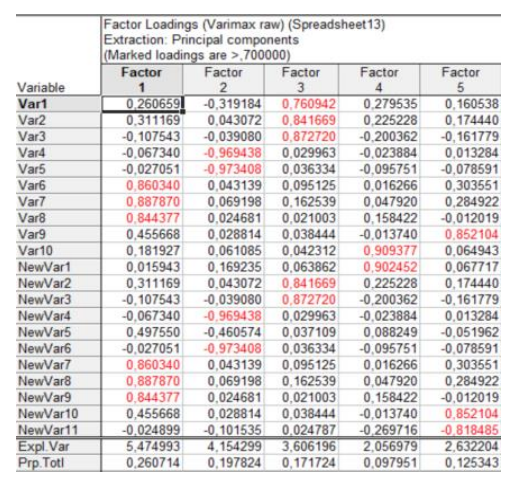

Figure 5. Factor load of indicators on resource and innovative directions of the analysis Sources: developed by the authors.

A sufficient number of factors is 5 , which is due to the value of the accumulated variance $-85.36 \%$ (Figure 6).

\begin{tabular}{|c|c|c|c|c|}
\hline \multirow[b]{2}{*}{ Value } & \multicolumn{4}{|c|}{$\begin{array}{l}\text { Eigenvalues (Spreadsheet 13) } \\
\text { Extraction: Principal components }\end{array}$} \\
\hline & Eigenvalue & $\begin{array}{l}\% \text { Total } \\
\text { variance }\end{array}$ & $\begin{array}{l}\text { Cumulative } \\
\text { Eigenvalue }\end{array}$ & $\begin{array}{c}\text { Cumulative } \\
\%\end{array}$ \\
\hline 1 & 7.123588 & 33.92185 & 7,12359 & 33,92185 \\
\hline 2 & 4,365749 & 20,78 & 11,4 & 54,71113 \\
\hline 3 & 3,078658 & 14,66028 & 14,56800 & 69,37141 \\
\hline 4 & 1.803734 & 8.58921 & 16.37173 & 77.96062 \\
\hline 5 & 1.552940 & 7.39495 & 17.92467 & 85.35557 \\
\hline
\end{tabular}

Figure 6. The accumulated dispersion of factors by resource and innovation directions of

Sources: developed by the authors. analysis 
O., lastremska, U., Strokovych, O., lastremska, C., Kalantaridis, S., Nagy, M., Somosi Verense. Formation of Mutual Relations Between Enterprises and Business Partners in the Process of Preparation and Production of New Products

The value of factor loads of indicators for each factor (Figure 5) proved the feasibility of using partial indicators to assess the enterprise's success functioning; the factor loads greater than 0.7 . Thus, the impact of which on its production of new products is significant.

Based on factor loads, the following partial indicators were identified: financial autonomy ratio (R1), sales profitability ratio ( $R 2$ ), solvency ratio ( $R 3$ ), liquidity ratio (R4), financial stability ratio (R5), fixed assets renewal rate (R6), return on assets (R7), capital adequacy (R8), material efficiency (R9), share of investments in informatization to total volume of investments (R10), share of expenses for participation in exhibitions and other image events in the total expenses for sales of products (R11), share of investments in software in the total amount of investments for informatization (R12); the share of employees performing scientific and technical work (I1), share of current expenditures on technological innovations in total expenditures on innovations (I2), share of research and development expenditures in total expenditures on innovations (14), the share of costs for technological preparation of production in the total cost of innovation (I5), the share of costs for machinery, equipment, tools, other fixed assets and capital costs associated with the implementation of innovations in the total cost of innovation (I6), the share of marketing and advertising costs in the total cost of innovation (I7), the share of innovative products in the total shipped (18). According to the formula of the integrated indicator of the enterprise functioning success, its actual quantitative values for the studied enterprises were calculated (Table 5).

Table 5. Quantitative values of integrated indicators of activity machine-building enterprises of Kharkiv region for 2015-2019

\begin{tabular}{lrrrrr}
\hline Name of Company & $\mathbf{2 0 1 5}$ & $\mathbf{2 0 1 6}$ & $\mathbf{2 0 1 7}$ & $\mathbf{2 0 1 8}$ & $\mathbf{2 0 1 9}$ \\
\hline PJSC «Kharkiv Bearing Plant» & 0,385 & 0,419 & 0,382 & 0,429 & 0,417 \\
JSC «Turboatom» & 0,332 & 0,327 & 0,347 & 0,330 & 0,326 \\
PJSC Pivdenkabel Plant & 0,315 & 0,302 & 0,295 & 0,304 & 0,289 \\
PJSC «Vovchansky Aggregate Plant» & 0,346 & 0,354 & 0,342 & 0,348 & 0,327 \\
State Enterprise «Kharkiv Machine-Building Plant» FED» & 0,315 & 0,328 & 0,331 & 0,328 & 0,335 \\
SE «Electrovazhmash Plant» & 0,298 & 0,262 & 0,305 & 0,284 & 0,296 \\
PJSC «Electromachine» & 0,265 & 0,277 & 0,267 & 0,255 & 0,257 \\
PJSC Kharkiv Electrotechnical Plant Ukrelectromash & 0,271 & 0,262 & 0,249 & 0,245 & 0,249 \\
PJSC «Plant. Frunze» & 0,232 & 0,255 & 0,216 & 0,220 & 0,249 \\
PJSC «Kharkiv Tractor Plant» & 0,251 & 0,209 & 0,223 & 0,276 & 0,253 \\
PJSC «Kharkiv Machine-Building Plant» Korum Svitlo & 0,262 & 0,250 & 0,282 & 0,239 & 0,224 \\
Shakhtyar» & & & & 0,251 & 0,258 \\
Private JSC «Kharkiv Plant of Stamps and Molds» & 0,252 & 0,250 & 0,215 \\
\hline
\end{tabular}

Sources: developed by the authors.

According to Table 5, the best success of the functioning enterprise is PJSC «Kharkiv Bearing Plant», PJSC «Turboatom», PJSC «Vovchansky Aggregate Plant», the worst - Private JSC «Kharkiv Plant of Stamps and Molds», PJSC «Plant named after Frunze».

According to the calculated values of integrated indicators (Table 5), the functioning enterprises' success is not significant, as their maximum values should be close to one. The obtained low quantitative values of integrated indicators are explained by the objective economic situation at the enterprises. Subjective and objective components of the relationship between the enterprise and business partners in preparation for the release and production of new products, which was manifested in the objective quantitative results of management of the use of economic resources by the supplier and subjective qualitative ideas of the manufacturer the cooperation effectiveness in the process of preparation for the release of new products are unequal to determine the type of relationship, strategic alternatives and information tools for their formation and management. It is advisable to take into account quantitatively in 
O., lastremska, U., Strokovych, O., lastremska, C., Kalantaridis, S., Nagy, M., Somosi Verense. Formation of Mutual Relations Between Enterprises and Business Partners in the Process of Preparation and Production of New Products

the overall integrated indicator, which could be calculated by additive convolution, taking into account the coefficients of its components significance, namely - the success and effectiveness of cooperation, because these components and factors interact with new products.

The expert survey method was used to quantify the significance of the objective and subjective components to calculate the partner priority's generalized integral indicator. As experts, 2 representative groups of specialists from among the representatives of enterprises and their partners were interviewed. Thus, it allowed determining the coefficients of significance. The concordance coefficient is $W=0.36$, which indicates a weak but sufficient degree of agreement between experts' opinions. For assessing the significance of the concordance coefficient, the Pearson agreement criterion was calculated: $x^{2}=19.85$. The calculated $x^{2}$ compared to the tabular value for the number of degrees of freedom $K=n-1=6-1=5$ and at a given level of significance $\alpha=0.05$ is much larger than the tabular (estimated 19.85; tabular 11.07050). The value $W=0.36$ is significant and not accidental. Therefore, the results obtained make sense and could be used in research. In turn, the experts agreed and suggested the possibility of using the significant coefficients of the objective (0.606) and subjective (0.394) components for enterprises and their business partners to calculate a generalized integrated indicator of partner priority. Therefore, to identify the preferred business partners that could meet the required effectiveness of cooperation and meet the demand of economic entities based on the efficient use of economic resources, the generalized integrated indicator's quantitative values characterized the business partner's priority. According to the generalized integrated indicator's calculated value, it was possible to rank the potential business partners' whole set. Table 6 presents the results of the analysis.

Table 6. The value of integrated indicators of the quality of the relationship between the enterprise and business partners in preparation for the release and production of new products (2019)

\begin{tabular}{|c|c|c|c|c|}
\hline \multirow[b]{2}{*}{ Name of Company } & \multicolumn{2}{|c|}{ Integral indicators } & \multirow{2}{*}{$\begin{array}{c}\text { Generalized } \\
\text { integrated indicator of } \\
\text { business partner } \\
\text { priority }\end{array}$} & \multirow[b]{2}{*}{$\begin{array}{l}\text { Company } \\
\text { rating }\end{array}$} \\
\hline & $\begin{array}{l}\text { effectiveness of } \\
\text { cooperation }\end{array}$ & $\begin{array}{l}\text { successful } \\
\text { functioning }\end{array}$ & & \\
\hline PJSC «Kharkiv Bearing Plant» & 0,98092 & 0,417 & 0,639184 & 1 \\
\hline JSC «Turboatom» & 0,96422 & 0,326 & 0,577459 & 2 \\
\hline PJSC Pivdenkabel Plant & 0,81708 & 0,289 & 0,497064 & 5 \\
\hline $\begin{array}{l}\text { PJSC «Vovchansky Aggregate } \\
\text { Plant» }\end{array}$ & 0,81998 & 0,327 & 0,521234 & 4 \\
\hline $\begin{array}{l}\text { State Enterprise «Kharkiv } \\
\text { Machine-Building Plant» FED» }\end{array}$ & 0,83754 & 0,335 & 0,533001 & 3 \\
\hline SE «Electrovazhmash Plant» & 0,76306 & 0,296 & 0,480022 & 6 \\
\hline PJSC «Electromachine» & 0,761 & 0,257 & 0,455576 & 9 \\
\hline $\begin{array}{l}\text { PJSC Kharkiv Electrotechnical } \\
\text { Plant Ukrelectromash }\end{array}$ & 0,7809 & 0,249 & 0,458569 & 8 \\
\hline PJSC «Plant. Frunze» & 0,78308 & 0,249 & 0,459428 & 7 \\
\hline PJSC «Kharkiv Tractor Plant» & 0,61924 & 0,253 & 0,397299 & 10 \\
\hline $\begin{array}{l}\text { PJSC «Kharkiv Machine-Building } \\
\text { Plant» Korum Svitlo Shakhtyar» }\end{array}$ & 0,61924 & 0,224 & 0,379725 & 12 \\
\hline $\begin{array}{l}\text { PJSC «Kharkiv Plant of Stamps } \\
\text { and Molds» }\end{array}$ & 0,65486 & 0,215 & 0,388305 & 11 \\
\hline
\end{tabular}

Sources: developed by the authors.

Based on the results presented in Table 6, it is possible to assess business partners' priority for individual components and general for a generalized integrated indicator of priority, which characterizes 
O., lastremska, U., Strokovych, O., lastremska, C., Kalantaridis, S., Nagy, M., Somosi Verense. Formation of Mutual Relations Between Enterprises and Business Partners in the Process of Preparation and Production of New Products

business partners' competence to produce new products. PJSC «Kharkiv Bearing Plant» has the best rating, and PJSC «Kharkiv Machine-Building Plant «Korum Svitlo Shakhtar» has the worst rating.

For making sound management decisions on cooperation with business partners for the preparation and production of new products by quantitative values of the generalized integrated indicator of priority of business partners, it is also necessary to provide these quantitative values with qualitative interpretation. For each of them, it is possible to form recommendations on using the most effective models of relationships. For this purpose, it is advisable to use the Harrington scale adapted to the conditions of management in Ukraine, which was developed for machine-building enterprises by lastremska (2006) and uses the provisions of fuzzy set theory on constructed membership functions that characterize the boundaries of clear and fuzzy intervals: from 0 to 0,19 - low level, from 0.19 to 0.30 - medium or low, from 0.30 to 0.37 - medium, from 0.37 to 0.56 - high or medium and from 0.56 to 1.0 - high level. Since the practical use of fuzzy intervals makes it difficult to make management decisions about partner priorities and use relationship models, it is possible to move to clear intervals «low», «medium», «high» by distributing fuzzy intervals at the level of segments according to the standard distribution membership functions. Thus, the boundaries of clear intervals of quality levels of the generalized integrated indicator of priority of partners for cooperation in the preparation and production of new products are as follows: low - $(0.0-0.245)$, medium - $(0.245-0.455)$, high $-(0.455-1.0)$. Based on the presented limits of clear intervals of the generalized integrated indicator, the investigated enterprises in 2019 will be distributed as follows: low level - 0; average level - 25\%; high level - $75 \%$.

This division of enterprises confirms the need to use effective models of enterprise relations with business partners effectively. Features of model types of the interrelation of manufacturer enterprise with the enterprises-business partners consist of generalization and development of the existing models offered by Kulikov and Sihaieva (2009). Considering the peculiarities of new products, which are inherent in the products of industrial and technical purposes of the machine-building industry, the types of existing models in their essence and content concerning partnerships were proposed to distribute them by quality priority levels of partner companies. Using the following classification features: the competence of persons who make decisions on the formation of partnerships, the time of obtaining the result from the partnership, the conditions for obtaining the effect, the purpose of cooperation. Thus, Table 7 presents the recommended effective relationship models for preparing and producing new products under the qualitative levels of partner companies' priority.

Table 7. Types of models of relationships for the preparation and production of new products with business partners following the qualitative levels of their priority

\begin{tabular}{|c|c|c|c|}
\hline \multirow{2}{*}{$\begin{array}{l}\text { Classification } \\
\text { feature of models } \\
\text { of the enterprises' } \\
\text { priority relations } \\
\text { business partners }\end{array}$} & \multicolumn{3}{|c|}{ Types of relationship models according to the qualitative levels of partners priority } \\
\hline & low & medium & high \\
\hline $\begin{array}{l}\text { competence of } \\
\text { persons who make } \\
\text { decisions on the } \\
\text { formation of } \\
\text { partnerships }\end{array}$ & $\begin{array}{l}\text { Decisions on cooperation } \\
\text { with the use of } \\
\text { intermediaries as } \\
\text { guarantors of the } \\
\text { professionalism of partner } \\
\text { companies }\end{array}$ & $\begin{array}{l}\text { Decision on cooperation on } \\
\text { the recommendations of } \\
\text { reference groups that } \\
\text { cooperated with business } \\
\text { partners }\end{array}$ & $\begin{array}{l}\text { Independent decision on } \\
\text { cooperation based on } \\
\text { own experience }\end{array}$ \\
\hline $\begin{array}{l}\text { the term of the } \\
\text { partnership }\end{array}$ & $\begin{array}{l}\text { The short-term expectation } \\
\text { of benefits from the } \\
\text { relationship for the } \\
\text { production of new products }\end{array}$ & $\begin{array}{l}\text { The medium-term } \\
\text { expectation of benefits from } \\
\text { the relationship for the } \\
\text { production of new products }\end{array}$ & $\begin{array}{l}\text { The long-term } \\
\text { expectation of benefits } \\
\text { from the relationship for }\end{array}$ \\
\hline
\end{tabular}


O., lastremska, U., Strokovych, O., lastremska, C., Kalantaridis, S., Nagy, M., Somosi Verense. Formation of Mutual Relations Between Enterprises and Business Partners in the Process of Preparation and Production of New Products

\begin{tabular}{|c|c|c|c|}
\hline & & & Countinued Table 7 \\
\hline $\begin{array}{c}\text { conditions for } \\
\text { obtaining the effect }\end{array}$ & $\begin{array}{l}\text { Fairway to the production } \\
\text { of innovative products that } \\
\text { are new to the company } \\
\text { and could form a short- } \\
\text { term effect }\end{array}$ & $\begin{array}{l}\text { Forward, that is mutational, } \\
\text { for the production of } \\
\text { innovative products that are } \\
\text { new to the market and able to } \\
\text { form a multiplier market effect }\end{array}$ & $\begin{array}{l}\text { the production of new } \\
\text { products } \\
\text { Lobbying for the } \\
\text { introduction of } \\
\text { innovations and } \\
\text { production of new } \\
\text { products, lobbying public, } \\
\text { capable of creating } \\
\text { sustainable effects for the } \\
\text { quality development of } \\
\text { society and filling the } \\
\text { state budget }\end{array}$ \\
\hline $\begin{array}{l}\text { the purpose of } \\
\text { cooperation }\end{array}$ & $\begin{array}{l}\text { Gaining benefits from the } \\
\text { effectiveness of } \\
\text { cooperation }\end{array}$ & $\begin{array}{l}\text { Gaining benefits from the } \\
\text { success of the functioning }\end{array}$ & $\begin{array}{l}\text { Gaining benefits from } \\
\text { both the effectiveness of } \\
\text { cooperation and the } \\
\text { success of functioning }\end{array}$ \\
\hline
\end{tabular}

Sources: developed by the authors.

The use of the proposed models of relationships with business partners in the production of new products would competently select partners and form a relationship with them that will meet the interests of manufacturers and business partners, considering their ability to use all economic resources, opportunities implementation of innovative activities, the success of cooperation following the priority of functioning.

Conclusions. Business partners are competent for successful functioning, as they have the necessary economic resources to prepare for the release of new products. Besides, partners are competent to respond to consumer needs changes, as they track new developments and produce innovative products and invest appropriate resources in this process. Partners are also competent in terms of the cooperation effectiveness they could provide. The manufacturer could analyze many business partner companies based on their ranking by priority level to evaluate all entities' relative assessment, determining their relative competence. The proposed models of relationships with business partners in the process of preparation and production of new products are the basis for competent selection of business partners and the formation of such relationships with them that will meet the interests of manufacturers and business partners, taking into account their ability to use all economic resources, opportunities for innovation, the success of cooperation following the priority of operation.

Author Contributions: conceptualization, methodology, software, validation, investigation, writingoriginal draft preparation - O.I., U.S., O.la., C.K., S.N., M.S.V.

\section{References}

Ahuja, G. (2000). Collaboration networks, structural holes, and innovation: A longitudinal study. Administrative science quarterly, 45(3), 425-455. [Google Scholar] [CrossRef]

Allen, T. J. (1977). Managing the flow of technology transfer and the dissemination of technological information within the R\&D organization.

Anand, B. N., \& Khanna, T. (2000). Do firms learn to create value? The case of alliances. Strategic management journal, 21(3), 295-315. [Google Scholar] [CrossRef]

Ariño, A., \& De La Torre, J. (1998). Learning from failure: Towards an evolutionary model of collaborative ventures. Organization science, 9(3), 306-325. [Google Scholar] [CrossRef]

Brown, S. L., \& Eisenhardt, K. M. (1997). The art of continuous change: Linking complexity theory and time-paced evolution in relentlessly shifting organizations. Administrative science quarterly, 1-34. [Google Scholar] [CrossRef] 
O., lastremska, U., Strokovych, O., lastremska, C., Kalantaridis, S., Nagy, M., Somosi Verense. Formation of Mutual Relations Between Enterprises and Business Partners in the Process of Preparation and Production of New Products

Chesbrough, H. W. (2003). Open innovation: The new imperative for creating and profiting from technology. Harvard Business Press. [Google Scholar]

Clark, K. B. (1991). Product Development Performance: Strategy. Organization, and Management in the World Auto Industry. [Google Scholar]

Davis, J. P. (2011). 'Network agency problems. MIT Sloan School of Management.

Davis, J. P., \& Eisenhardt, K. M. (2011). Rotating leadership and collaborative innovation: Recombination processes in symbiotic relationships. Administrative Science Quarterly, 56(2), 159-201. [Google Scholar] [CrossRef]

Davis, J. P., Eisenhardt, K. M., \& Bingham, C. B. (2007). Developing theory through simulation methods. Academy of Management Review, 32(2), 480-499. [Google Scholar] [CrossRef]

Davis, J. P., Eisenhardt, K. M., \& Bingham, C. B. (2009). Optimal structure, market dynamism, and the strategy of simple rules. Administrative science quarterly, 54(3), 413-452. [Google Scholar] [CrossRef]

Doz, Y. L. (1996). The evolution of cooperation in strategic alliances: initial conditions or learning processes?. Strategic management journal, 17(S1), 55-83. [Google Scholar] [CrossRef]

Gans, J. S., Hsu, D. H., \& Stern, S. (2002). When does start-up innovation spur the gale of creative destruction?. The Rand Journal of Economics, 33(4), 571. [Google Scholar]

Gulati, R. (1995). Does familiarity breed trust? The implications of repeated ties for contractual choice in alliances. Academy of management journal, 38(1), 85-112. [Google Scholar] [CrossRef

Hagedoorn, J. (1993). Understanding the rationale of strategic technology partnering: Interorganizational modes of cooperation and sectoral differences. Strategic management journal, 14(5), 371-385. [Google Scholar] [CrossRef]

lastremska, O. \& Sihaieva, T. (2009). The main types of models of interaction of market participants in the investment process. Lieberman readings: economic heritage and modern problems, (pp. 188-199). Kharkiv: VD «INZhEK».

lastremska, O. (2006). Application of fuzzy set theory for qualitative differentiation of enterprise characteristics (on the example of machine-building, food and light industry enterprises). Development economics, 3(39), 95 - 101.

Kale, P., Dyer, J. H., \& Singh, H. (2002). Alliance capability, stock market response, and long-term alliance success: the role of the alliance function. Strategic management journal, 23(8), 747-767. [Google Scholar] [CrossRef]

Katila, R. (2002). New product search over time: past ideas in their prime?. Academy of Management journal, 45(5), 995-1010. [Google Scholar] [CrossRef]

Katila, R., Rosenberger, J. D., \& Eisenhardt, K. M. (2008). Swimming with sharks: Technology ventures, defense mechanisms and corporate relationships. Administrative science quarterly, 53(2), 295-332. [Google Scholar] [CrossRef]

Kulikov, P., \& Sihaieva, T. (2009). Features of the company's interaction with the external environment in the investment process. International Scientific and Practical Conference (pp. 190-193). Kharkiv: VD «INZhEK».

Mayer, K. J., \& Argyres, N. S. (2004). Learning to contract: Evidence from the personal computer industry. Organization science, 15(4), 394-410. [Google Scholar] [CrossRef]

O'Mahony, S., \& Ferraro, F. (2007). The emergence of governance in an open source community. Academy of Management Journal, 50(5), 1079-1106. [Google Scholar] [CrossRef]

Powell, W. W., Koput, K. W., \& Smith-Doerr, L. (1996). Interorganizational collaboration and the locus of innovation: Networks of learning in biotechnology. Administrative science quarterly, 116-145. [Google Scholar] [CrossRef]

Stuart, T. E. (2000). Interorganizational alliances and the performance of firms: a study of growth and innovation rates in a hightechnology industry. Strategic management journal, 21(8), 791-811. [Google Scholar] [CrossRef]

Uzzi, B. (1996). The sources and consequences of embeddedness for the economic performance of organizations: The network effect. American sociological review, 674-698. [Google Scholar] [CrossRef] Україна

Олена Ястремська, д.е.н., професор, Харківський національний економічний університет імені Семена Кузнеця

Ганна Строкович, д.е.н., доцент, Харківський національний економічний університет імені Семена Кузнеця, Україна

Олеся Ястремська, к е.н., доцент, Харківський національний економічний університет імені Семена Кузнеця, Україна

Калантаридис Христос, Ph.D., професор, Лондонський університет Метрополітен, Велика Британія

Саболч Hari, Ph.D., Університет у Мішкольці, Угорщина

Мариан Вересне Сомоси, Ph.D., професор, Університет у Мішкольці, Угорщина

Формування взаємовідносин між підприємствами та бізнес-партнерами в процесі підготовки та виробництва нової продукції

У статті узагальнено наукові підходи щодо покращення якості взаємовідносин між підприємством та бізнес-партнерами при підготовці та виробництві нової продукції за сучасних економічних умов. Основною метою дослідження є обґрунтування та розроблення методологічного підходу до визначення дієвих моделей взаємовідносин між підприємством та бізнеспартнерами у процесі підготовки та виробництва нової продукції. Для досягнення поставленої мети, дослідження проведено у наступній логічній послідовності. На першому етапі проаналізовано наявні підходи щодо формування взаємовідносин між підприємством та бізнес-партнерами при виробництві нової продукції. На другому етапі здійснено збір фактичних даних щодо функціонування підприємств машинобудівної промисловості. Таким чином, це дозволило оцінити результативність 
O., lastremska, U., Strokovych, O., lastremska, C., Kalantaridis, S., Nagy, M., Somosi Verense. Formation of Mutual Relations Between Enterprises and Business Partners in the Process of Preparation and Production of New Products

співпраці та якість взаємовідносин між підприємством та бізнес-партнерами в процесі підготовки та виробництва нової продукції. На третьому етапі встановлено пріоритети бізнес-партнерів. На четвертому етапі дослідження визначено взаємозв'язок між якісними рівнями пріоритетності бізнес-партнерів та доцільними моделями взаємовідносин в процесі підготовки та виробництва нової продукції. Емпіричне дослідження проведено з використанням інструментарію багатовимірного факторного аналізу, методів експертних оцінок та адитивної згортки, графічного та структурно-логічного методів. У ході дослідження проведено анкетування представників 12 машинобудівних підприємств 3 метою оцінки результативності співпраці. За результатами багатовимірного факторного аналізу виявлено та обірунтовано часткові показники, які було узагальнено для прийняття рішень щодо можливої співпраці із бізнес-партнерами при підготовці та виробництві нової продукції. На основі розрахунку інтегрального показника встановлено пріоритети бізнес-партнерів та визначено якість їх взаємовідносин із машинобудівними підприємствами. При цьому авторами застосовано уточнену для економічних умов України шкалу Харінгтона для визначення якісного рівня пріоритетності підприємств-партнерів. За результатами запропоновано дієві моделі взаємовідносин для підготовки та виробництва нової продукції. Результати проведеного дослідження можуть бути корисними для покращення якості, формування та підтримки взаємовідносин між підприємствами та бізнес-партнерами при підготовці та виробництві нової продукції.

Ключові слова: нові продукти, ефективність, співпраця, успіх, функціонування, діловий партнер, відносини. 